\title{
Evaluation of School Fatigue and Social Relationships in a Group of Students from General Knowledge High Schools in lasi County
}

\author{
Albu Adriana ${ }^{1}$, Dima Florin ${ }^{1, ~}$, Abdulan Irina ${ }^{2}$, Cărăuşu Mihaela ${ }^{3}$ \\ ${ }^{1}$ Department of Hygiene, University of Medicine and Pharmacy, Iasi, Romania \\ ${ }^{2}$ Department of Internal Medicine, University of Medicine and Pharmacy, Iasi, Romania \\ ${ }^{3}$ Department of Public Health, University of Medicine and Pharmacy, Iasi, Romania
}

Email address:

dimaflorin88@yahoo.com (D. Florin)

${ }^{*}$ Corresponding author

\section{To cite this article:}

Albu Adriana, Dima Florin, Abdulan Irina, Cărăuşu Mihaela. Evaluation of School Fatigue and Social Relationships in a Group of Students from General Knowledge High Schools in Iasi County. Education Journal. Vol. 7, No. 1, 2018, pp. 1-4. doi: 10.11648/j.edu.20180701.11

Received: January 8, 2018; Accepted: January 19, 2018; Published: MM DD, 2018

\begin{abstract}
School activity should be carefully monitored to avoid over-stress and pathological fatigue. In this context it is important to evaluate social relationships and the phenomenon of school fatigue. The study was carried out on a group of 221 pupils from two high schools in Iasi County. We used a questionnaire that investigates school fatigue, how pupils spend leisure time and the social relationships of the students. Fatigue is particularly intense in high school students in Iasi. A third of adolescents do not watch TV (television), and the computer is not used every day by over $15 \%$ of young people. There are pupils who do not have real friends and do not spend their evenings out on the town with friends. Most parents are not concerned about school activity and leisure time for adolescents. The interviewed students have many problems that should be in the attention of teachers and parents.
\end{abstract}

Keywords: Fatigue, Free Time, Parental Supervision

\section{Introduction}

School activity is an integral part of the life and essential for the maturity of a child. However, the child is incompletely developed and immature, so the demands to which they are subjected must be carefully evaluated by those skilled in this field. An overly modest request does not allow the child to exploit his full potential, but a request that is too intense can be easily associated with the risk of overloading and school failure [5].

To avoid the risk of triggering overloading reactions, a student's daily schedule must be properly organized. There are situations where leisure activities become sources of fatigue; for example, time spent in front of the TV and, above all, the computer screen, which may exceed the accepted norms (up to one hour for each activity). Time spent in front of the computer screen can be associated with a tendency toward focusing on online friendships and giving up real relationships [4].

There are also sites discussing body appearance, weight and diet regimes, which expose young people to the risk of eating disorders [3].

The teenager wants to be independent but needs parental supervision. The best situation is where parents cultivate certain standards, certain models, which will allow children to acquire appropriate affective traits and social skills. Studies conducted by specialists have highlighted the importance of family education in all spheres such as personality training, intellectual, moral and physical development and success in personal and professional life [11].

The aim of our work is the evaluation of the presence of school fatigue in the students in the studied group, knowing how pupils spend their free time, paying special attention to time spent on television and computer use and the assessment of 
social relationships in two directions represented by the presence of real friends and relationship between child and parents.

\section{Method}

\subsection{Sample}

The study was carried out on a group of 221 pupils from two high schools in Iasi County. There are 112 students from Garabet Ibraileanu National College in Iasi (big city, county seat) and 109 pupils from the Mihail Sadovenu National College in Pascani (a small town $60 \mathrm{~km}$ away from Iasi). The students surveyed are from the $10^{\text {th }}$ and $11^{\text {th }}$ grades. The two high schools studied are general knowledge schools with mathematics-physics and philology as main areas of study. Statistical processing was done using the Pearson CHIsquared Test.

\subsection{Objectives}

The research was focused in three directions, represented by the appreciation of the phenomenon of school fatigue, leisure time and social relationships.

\subsubsection{School Fatigue}

School fatigue is assessed based on three questions:

Are you feeling tired?: 1)Often 2)Rarely 3)Never;

Compared to your classmates do you feel tired? : 1) More often 2) The same 3) Less often;

During the week are you more tired: 1) At the start 2) In the middle 3) At the end;

\subsubsection{Free Time}

Leisure time activities were measured based on two questions related to the time spent in front of the TV screen and the computer:

How many hours a day do you spend in front of the TV?: 1) None 2) 0,5-1h 3) 2-3h 4) 4-5h;

How many hours a day do you spend at the computer?: 1) None 2) 0,5-1h 3) 2-3h 4) 4-5h;

\subsubsection{Social Relationships}

The third studied aspect is about social relationships based on two directions - the group of friends and parents:

How many true friends (close friends) do you have? 1) None 2) One 3) Two 4) Three or more;

In general, how many evenings per week do you go out with friends after school? 1) Zero 2) 1 evening 3) 23evenings 4) 4-5 evenings 5) 6-7 evenings;

Do parents (at least one of them) have enough time to help you prepare your homework? 1) Always 2) Often 3) Seldom 4) Never;

Do parents have time to organize (or help you organize) your free time? 1) Always 2) Often 3) Seldom 4) Never;

\section{Results}

The results obtained will be presented starting from the three main ideas: school fatigue, recreational activities and social relationships.

School fatigue is a physiological phenomenon that occurs when the student's physical and intellectual effort is exceeded. $51.58 \%$ of the pupils responded with "often", which is a big problem. In fact, half of the students surveyed feel intense fatigue that can easily become a chronic one (Table 1).

Table 1. The presence of fatigue in questioned students.

\begin{tabular}{lllll}
\hline & Often & Rarely & Never & Total \\
\hline Iasi & 75 & 37 & 0 & 112 \\
Pascani & 39 & 69 & 1 & 109 \\
Total & 114 & 106 & 1 & 221 \\
$\%$ & 51.58 & 47.96 & 0.45 & \\
\hline
\end{tabular}

The calculated differences between the two groups are statistically significant at a $\mathrm{p}<0.001\left(f=2, \chi^{2}=21.913\right)$ and draw our attention to the high school students from Iasi who experience fatigue more often and more intensely.

Another aspect studied is the frequency with which fatigue occurs, compared with classmates. There are 22.62\% "More often" responses, which may be a problem. Those students study more, are more ambitious, or require a longer time for studying (Table 2).

Table 2. Frequency of pupils' fatigue compared to classmates.

\begin{tabular}{lllll}
\hline & Iasi & Pascani & Total & \% \\
\hline More often & 32 & 18 & 50 & 22.62 \\
The same & 66 & 67 & 133 & 60.18 \\
Less often & 14 & 24 & 38 & 17.19 \\
\hline
\end{tabular}

Calculated differences are statistically significant at a $\mathrm{p}<0.05\left(f=2, \chi^{2}=6.606\right)$, which results in a higher frequency of students who feel more tired at the Iasi high school.

Physiological fatigue occurs after a week of work so, should naturally occur at the end of the school week. This is the case for only $31.22 \%$ of the surveyed students. Our attention is drawn to the $30.76 \%$ young people who feel tired at the beginning of the week after a busy weekend (Table 3 ).

Table 3. Moment of fatigue during the week.

\begin{tabular}{lllll}
\hline & Iasi & Pascani & Total & \% \\
\hline At the start & 33 & 35 & 68 & 30.76 \\
In the middle & 53 & 31 & 84 & 38.00 \\
At the end & 26 & 43 & 69 & 31.22 \\
\hline
\end{tabular}

Differences calculated are statistically significant for $\mathrm{p}<0.01\left(f=2, \chi^{2}=9.873\right)$, a result that also draws our attention to students from the Iasi high school.

There are many factors that generate fatigue; factors relating to school activity, but also to how students spend their leisure time. Young people have the tendency to spend too much time watching TV or using the computer, which intensifies fatigue [7].

In the studied group, the situation is surprising, as $36.19 \%$ of young people do not watch television programs at all. An adequate viewing time (up to one hour a day) is present in $39.81 \%$ of cases. We must take note of the $4.07 \%$ of young people who sit in front of the TV for 4-5 hours, daily (Table 4). 
Table 4. The time spent by students in front of the TV screen.

\begin{tabular}{lllll}
\hline & None & $\mathbf{0 . 5}-\mathbf{1}$ hour & $\mathbf{2 - 3}$ hours & $\mathbf{4 - 5}$ hours \\
\hline Iasi & 51 & 39 & 17 & 5 \\
Pascani & 29 & 49 & 27 & 4 \\
Total & 80 & 88 & 44 & 9 \\
$\%$ & 36.19 & 39.81 & 19.90 & 4.07 \\
\hline
\end{tabular}

Young people from Iasi high school frequently opt for "None", so differences between the two groups are statistically significant at $\mathrm{p}<0.05 \quad\left(f=3, \chi^{2}=9.561\right)$. These students are very busy and have no time to relax in front of the TV screen.

The study is completed by an assessment of the time spent in front of the computer. The dominant responses are "2-3 hours" (37.10\%) and "0.5-1 hour" (28.05\%). Normally, the student can spend an hour per day on the computer, a result present in almost $30 \%$ of the surveyed students. Our attention is also drawn to the $16.74 \%$ of young people who marked the "none" response (Table 5).

Table 5. Time spent on the computer.

\begin{tabular}{lllll}
\hline & None & $\mathbf{0 . 5}-\mathbf{1}$ hour & $\mathbf{2 - 3}$ hours & $\mathbf{4 - 5}$ hours \\
\hline Iasi & 22 & 35 & 39 & 16 \\
Pascani & 15 & 27 & 43 & 24 \\
Total & 37 & 62 & 82 & 40 \\
$\%$ & 16.74 & 28.05 & 37.10 & 18.09 \\
\hline
\end{tabular}

The differences calculated are statistically insignificant ( $\mathrm{p}>0.05, f=3, \chi^{2}=4.118$ ), an easily understood result. Students from the high school in Iasi use the computer, even if they are tired, but they do not use it excessively. The time spent on the computer is much higher compared to the time spent watching television, the calculated differences being statistically significant for $\mathrm{p}<0.0001\left(f=3, \chi^{2}=51,380\right)$.

An extremely important element for the positive evolution of adolescents is represented by social relationships. During adolescence, the group of friends forms and the relationship with parents changes.

In most cases, students have three or more real friends $(45.24 \%)$ or two real friends $(32.12 \%)$. Our attention is drawn to the $4.52 \%$ of young people who choose the "None" response which raises questions about the isolation trend. Thus, the differences calculated are statistically insignificant ( $\left.>0.05, f=3, \chi^{2}=6.754\right)$ (Table 6).

Table 6. The number of true friends.

\begin{tabular}{lllll}
\hline & Iasi & Pascani & Total & \% \\
\hline None & 9 & 1 & 10 & 4.52 \\
One & 20 & 20 & 40 & 18.09 \\
Two & 36 & 35 & 71 & 32.12 \\
Three or more & 47 & 53 & 100 & 45.24 \\
\hline
\end{tabular}

The result is quite good because in another study at a high school in Bacau, $14.90 \%$ young people are without any true friends [1].

The presence of friends is also associated with going out on the town together. In most cases, young people spend 2-3 evenings in town with friends $(35.74 \%)$ or one evening (28.95\%) (Table 7).
Table 7. Evenings spent with friends outside the school.

\begin{tabular}{lllll}
\hline & Iasi & Pascani & Total & \% \\
\hline Zero & 24 & 26 & 50 & 22.62 \\
1 evening & 40 & 24 & 64 & 28.95 \\
2-3 evenings & 35 & 44 & 79 & 35.74 \\
4-5 evenings & 5 & 10 & 15 & 6.78 \\
6-7 evenings & 8 & 5 & 13 & 5.88 \\
\hline
\end{tabular}

The presence of $22.62 \%$ of young people who choose the "Zero" option is noticed, so they do not spend any time at all with friends in town. It is a surprising result particularly because of the fact that only $4.52 \%$ of adolescents have no friends. Such situations are present in both high schools, the calculated differences being statistically insignificant ( $\left.\mathrm{p}>0.05, f=4, \chi^{2}=7.440\right)$.

Parents should still play an important role in the lives of young people. Most parents are rarely concerned with the school activity of young people $(41.17 \%)$ or are not concerned at all (26.69\%) (Table 8).

Table 8. Parents' preoccupation with the pupil's school activity.

\begin{tabular}{lllll}
\hline & Always & Often & Rarely & Never \\
\hline Iasi & 13 & 27 & 41 & 31 \\
Pascani & 10 & 21 & 50 & 28 \\
Total & 23 & 48 & 91 & 59 \\
$\%$ & 10.40 & 21.71 & 41.17 & 26.69 \\
\hline
\end{tabular}

The modest preoccupation of parents for pupils' school activity is present in both groups, the differences being statistically insignificant ( $\mathrm{p}>0.05, f=3, \chi^{2}=2.136$ ). Schooling can be the concern of the teachers, but leisure is a concern of the family [8]. Only in $9.95 \%$ of cases parents are constantly concerned about this. The "Always" responses dominate $(38.00 \%)$ followed by the "never" responses (20.36\%), a result present in both communities. Differences calculated are obviously insignificant statistically $(\mathrm{p}>0.05, f=3$, $\chi^{2}=0.949$ ) (Table 9).

Table 9. Parental preoccupation with adolescents' leisure time.

\begin{tabular}{lllll}
\hline & Always & Often & Seldom & Never \\
\hline Iasi & 12 & 33 & 42 & 25 \\
Pascani & 10 & 37 & 42 & 20 \\
Total & 22 & 70 & 84 & 45 \\
$\%$ & 9.95 & 31.67 & 38.00 & 20.36 \\
\hline
\end{tabular}

Lack of parental concern about how children spend their free time is a risk factor that may be associated with smoking, alcohol consumption, or antisocial behaviors [12].

\section{Discussion}

The study focuses on three main directions, which are essential for the momentum of adolescents' daily activities: assessing the phenomenon of school fatigue, studying ways of spending leisure time and social relationships.

Assessment of fatigue is very important because it can easily trigger overload, and then, pathological fatigue.

Intense fatigue is recognized by half of the surveyed students, which is the expected outcome because they are 
studying at national colleges, elite schools where school performance is very important. A similar score $(45.99 \%$ of students) was also obtained in another study conducted at three high schools in Iasi, a general knowledge high school, a music high school and a sports high school [2].

In class, pupils discuss various issues, compare their results and even the level of effort required. In this context, it was important to ask them to appraise the intensity of their fatigue compared to their colleagues. In most cases (60.18\%) the answer is "The same", logical result considering that they are in the same class and are subject to the same requests.

In the studied group, physiological fatigue is present in $31.22 \%$ of cases compared to the study conducted on three schools, where fatigue was present in only $18.98 \%$ of interviewed young people [2].

In the studied group there is an increase in the frequency of students who feel a tired, a phenomenon that is worrying.

Adolescents' favorite way of spending leisure time is watching TV or using the computer.

In a study conducted in the Republic of Croatia, $16.908 \%$ of students spent one hour at the computer (which is recommended), but the dominant values are 2 hours (28.502\%) and 3 hours (21.739\%). Basically, $50 \%$ of the students spend too much time on the computer, reaching 2-3 hours per day, which is worrying. In this study, $14,09 \%$ of pupils sit for 4-5 hours at the computer. These students spend a lot of time in front of the computer, some of whom are accustomed to the computer from the age of three $(6,507 \%)$ or four years $(10,616 \%)[9]$.

In a study from the United States of America, $33.2 \%$ of young people sit in front of the TV for 3 hours or more, and $40.3 \%$ of young people use the computer daily for 3 or more hours [10].

Social relationships are geared towards forming a group of friends and reducing the roles of parents.

In a study carried out in Japan, $29.9 \%$ of young people have a preference for loneliness, even though only $8.4 \%$ are socially isolated [6]. The result is similar to what we have obtained; $22.62 \%$ of students have a preference for loneliness (do not spend evenings with friends) but only $4.52 \%$ are socially isolated (do not have real friends). Parents are less concerned about school activity and leisure time, so antisocial or risk behaviors can occur [12].

\section{Conclusion}

School fatigue is present in students of both high schools, but it has a higher intensity in the high school from Iasi, an elite high school where competition is high. These students are less interested in TV programs, but they do not give up computer use.

Even if school demands are intense, young people have opportunities for friendships and spend time with friends. There are preferences for loneliness in some cases (they do not spend time in town even if they have close friends) and also a tendency towards isolation. These are issues that should be carefully monitored by specialists. Parents are less and less concerned about student activity, which can sometimes be a very big problem.

Such studies are important for specialists in the field, but, unfortunately, they are quite few.

\section{References}

[1] Albu A., Dima F., Chiper C. and Rada C. 2017, Evaluarea relatiilor sociale ale unui lot de adolescenti de la Colegiul Tehnic "Anghel Saliny" din Bacău, în Antropologie si Educatie, coordonatori Kozma A., Glavce C. si BălăceanuStolnici C., Bucuresti: Ed. Academiei Romane, 256-261.

[2] Albu A., Hodorcă R. M., Onose I., Negrea M. and Crăcană I., 2016, The evaluation of the scholar fatigue phenomen and some causative factors in a group of teenagers from Iasi, Global Journal of Sociology: Current Issues, 6(2), 44-49.

[3] Arseniev-Koeler A., Lee H., Mccomick and Moreno T., 2016, Proana: Pro-eating disorders Socialization on Twitter, Journal of Adolescent Health, 2016, 58, 659-664.

[4] Buonomo I., Cipriani I., Piperno S., Saddi I. and Fiorilli C., Internet and socialization: how internet use influences online and offline relationships. Anthropological Researches and Studies, 2015, 5, 3-10.

[5] Cosmovici A. and Iacob L. 2008, Psihologie scolară, Iasi: Ed. Polirom.

[6] Endo K., Ando S., Shimodera S., Yamasaki S., Usami S., Okazaki Y., Sasaki T., Richards M., Hatch S., and Nishida A., Preference for solitude, social isolation, suicidal ideation and self-harm in adolescents, Journal of Adolescent Health, 2017, 61,187-191.

[7] Etco C., Calmîc V. and Bahnarel I. 2013, Promovarea sănătătii si educatie pentru sănătate, Chisinău: Ed. Epigraf.

[8] Ferchiu A. N., 2017, Implicatii ale mediului familial în educatia copiilor, în Antropologie si Educatie, coordonatori Kozma A., Glavce C. si Bălăceanu-Stolnici C., Bucuresti: Ed. Academiei Romane, 175-182.

[9] Lazic J. L., Pavlina A. P. and Belovic T., 2017, The interest of elementary school students in computer science, New Trends and Issues Proceedings on Humanities and Social Sciences, vol. 4., Issue 1,232-238.

[10] Miller G., Sliwa S., Brener N., Park S. and Merlo C., 2016, School District Policies and Adolescent Soda consumption, Journal of Adolescent Health, 59, 17-23.

[11] Rada C. and Manu B., 2015, Educatia copiilor si controlul copiilor de către părinti: atitudini, comportamente, în Provocări ale familiei contemporane coordonatori Rada C. si Bistriceanu-Pantelimon C., Bucuresti: Ed. Universitară.

[12] Zilanawala A., Sacker A. and Kelly Y., 2017, Longitudinal Latent Cognitive Profiles and Psychosocial Well-being in early Adolescence, Journal of Adolescent Health, 61,493-500. 